\title{
Cadmium Distribution in Tobacco Growing Soil Fractions: Its Influence on Dried Leaf Contents
}

\author{
Eduardo Ortega $^{*}$, Francisco Javier Lozano ${ }^{2}$, Carlos Manuel Asensio ${ }^{2}$, Sara Montoya ${ }^{1}$, \\ Maria Luisa Lorenzo ${ }^{3}$ \\ ${ }^{1}$ Department of Edaphology and Agricultural Chemistry, College of Pharmacy, University of Granada, University Campus Cartuja, \\ Granada, Spain; ${ }^{2}$ Department of Edaphology and Agricultural Chemistry, Graduate School of Engineering, University of Almeria, \\ Almeria, Spain; ${ }^{3}$ Department of Nutrition and Bromatology, College of Pharmacy, University of Granada, University Campus Car- \\ tuja, Granada, Spain. \\ Email: *eortega@ugr.es
}

Received July $3^{\text {rd }}, 2013$; revised August $5^{\text {th }}, 2013$; accepted September $6^{\text {th }}, 2013$

Copyright (C) 2013 Eduardo Ortega et al. This is an open access article distributed under the Creative Commons Attribution License, which permits unrestricted use, distribution, and reproduction in any medium, provided the original work is properly cited.

\begin{abstract}
Many authors have studied cadmium concentrations in tobacco leaves. However, crops such as tobacco store Cd mainly in their leaves and these are for human consumption. The objective of this study is to establish the cadmium levels present in each of the soils fractions throughout the growing period of tobacco plants, and to examine the influence of these fractions on the total content cadmium in dried leaves. The field select is situated near of Granada city (soils from Vega de Granada) loamy calcareous thermic typic Xerorthent. The plant (Nicotiana tabacum, cvs. RJ36 variety), and the soil dedicated to the tobacco crop were contaminated with a fixed amount of $\mathrm{Cd}\left(100 \mathrm{mg} / \mathrm{kg}\right.$ of $\left.\mathrm{CdCl}_{2}\right)$ in the proximity of the root influence area. The contents of $\mathrm{Cd}$ are analysed in channel waters, in different soil fractions and dried tobacco leaves $(\mathrm{mg} / \mathrm{kg}$ ) with the different treatments. In conclusion, the water for irrigation is not a contamination risk for the soil even when user over lengthy periods of time. The fraction presenting higher average values is the one of Cd bound to $\mathrm{CaCO}_{3}$ with $0.161 \mathrm{ppm}$, and the $\mathrm{Cd}$ bioavailable fractions is second in importance, and propose a Cd content sequence in fractions, higher to lower: Cd-Carbonates $>$ Cd-Bioavailable > Cd-Organically bound > Cd-Exchangeable > Cd-Soluble.
\end{abstract}

Keywords: Cadmium Distribution; Tobacco Leaves

\section{Introduction}

Cadmium can be found in low concentrations in nature and is usually associated with $\mathrm{Zn}, \mathrm{Pb}$ or $\mathrm{Cu}$ [1]. It has increased rapidly in the last decades due to its vast utilisation in industry [2].

[3] quantify the amount of cadmium and other heavy metals such as lead, mercury and arsenic existing in England as a consequence of human activity. These same authors stress the relevance of the industrial manufacture of phosphate fertilisers with regard to the distribution and levels of cadmium found in water. In the case of the irrigation water used in Granada (Spain) [4] estimate a Cd concentration of $2.11 \mu \mathrm{g} / \mathrm{L}$. Cadmium contaminated rivers can also contaminate adjacent soils through the use of their waters in agriculture [5].

[6] estimates an average Cd concentration in the soil of

"Corresponding author.
$0.35 \mathrm{mg} / \mathrm{kg}$. [7] find a cadmium concentration in the soil which ranges from $0.06-1.11 \mathrm{mg} / \mathrm{kg}$, with a world average of $0.35 \mathrm{mg} / \mathrm{kg}$.

In soil samples taken from arable layers $(0-30 \mathrm{~cm})$ in Granada (Spain), [8] find amounts of cadmium of between $0.48-1.88 \mathrm{mg} / \mathrm{kg}$. According to [9], the factors which control the solubility of trace metals and their availability for plants include $\mathrm{Ph}$ content in organic matter, cation exchanging capability, texture, calcic carbonate equivalent, as well as the presence and types of micro organisms [10].

Analysis of the total Cadmium content in the soil does not yield sufficient information about its mobility, availability and biological effects [11]. In order to predict its availability and degree of toxicity it is necessary to know its chemical form [12].

Many sequential extractions are based on the scheme devised by [13] or on modifications of it. Other strategies 
use simple extractions with or without progressive acidification [12]. The extraction techniques most frequently used in soil utilise only one extractant, the content of which in one element, present in this phase, is correlated to the availability for the plant and can be used to predict its absorption by the soil [2].

Simple extraction methods can be classified according their common characteristics [7]: acids $\left(\mathrm{HC} 1, \mathrm{HNO}_{3}\right)$, agents (EDTAA, DTPA (+TEA)) ${ }^{1}$, tampon solutions (ammonic acetate, 1M/acetic acid buffer), non-tampon saline solutions $\left(\mathrm{CaCl}_{2}, \mathrm{MgCl}_{2} \mathrm{NaNO}_{3}, \mathrm{NH}_{4} \mathrm{NO}_{3}\right)$.

Plants absorb cadmium and can translocate it and accumulate it. Fortunately their absorption is limited [14, 15]. [16] establishes cadmium values below $1 \mathrm{mg} / \mathrm{kg}$ in plant remains, whilst [6] considers that the concentration value of cadmium in plants fluctuates between 0.1 and $2.4 \mathrm{mg} / \mathrm{kg}$.

Many authors have studied cadmium concentrations in tobacco leaves, thus Davies [17] found amounts close to $20 \mathrm{mg} / \mathrm{kg}$ (dry matter) when tobacco was grown on substrata containing high quantities of this element. Concentrations of up to $37 \mathrm{mg} / \mathrm{kg}$ have been found in experiments carried out with pot-grown tobacco [18].

[19] proved that high concentrations of cadmium accumulated in the roots, rather than in other parts of the plant, in tomato, corn, alfalfa, soya crops, but these roots are not for human consumption. However, crops such as lettuce, tobacco, carrots and potatoes, store Cd mainly in their leaves and these are for human consumption.

The objective of this study is to establish the cadmium levels present in each of the soil fractions throughout the growing period of tobacco plants, and to examine the influence of these fractions on the total content of cadmium in dried leaves.

\section{Materials and Methods}

The experimental field selected is situated in the 1009 topographic page of Granada (Figure 1), 1:50.000 scale of [20], located in the Cortijo Nuevo de Viñuela with the initial coordinates 30S 0441157-4117396, at a height of $618 \mathrm{~m}$ and NO-SE orientation.

The soil was classified according [21] as loamy calcareous thermic typic Xerorthent or calcaric Fluvisol, according to [22].

The plants used are of the Nicotiana tabacum, cvs. RJ36 variety.

Once they were planted in a permanent site, the experimentation area was established. The system chosen for the design of the experimental plot was the rectangular zigzag proposed by Sabbe and [23], albeit with several modifications [24].

The soils dedicated to the tobacco crop were contaminated with a fixed amount of $\mathrm{Cd}\left(100 \mathrm{mg} / \mathrm{kg}\right.$ of $\left.\mathrm{CdCl}_{2}\right)$ in the proximity of the root influence area and always in three repetitions. This contamination was carried out in three different stages of the tobacco crop cycle, that is to say, in June, July and August. Likewise, three soil witnesses have been maintained as well as non-contaminated plants in order to establish references with regard to the contaminated samples.

In June the three soil witness samples were collected (Figure 2), and the contamination of the first three plants was carried out. Thus, after a month the collection of soil samples from both the contaminated and the non-contaminated ones took place, and subsequently another three plants were contaminated. The sampling was repeated in this way throughout the tobacco crop cycle, which in the Granada Plain lasts between 90 and 100 days.

Later on, at the beginning of September, the tobacco plants were cut in order to initiate the drying stage. This process took place in the artisan drying sheds up to the beginning of November.

Soil and leaf samples were collected in the following way:

Soil: A 1000 g soil sample was obtained from the first

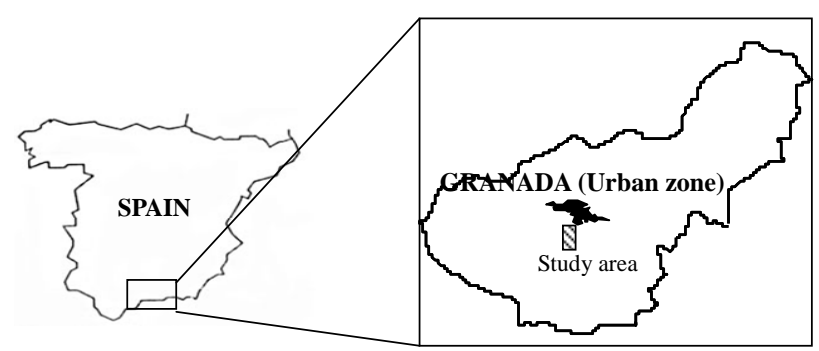

Figure 1. Location of study area.

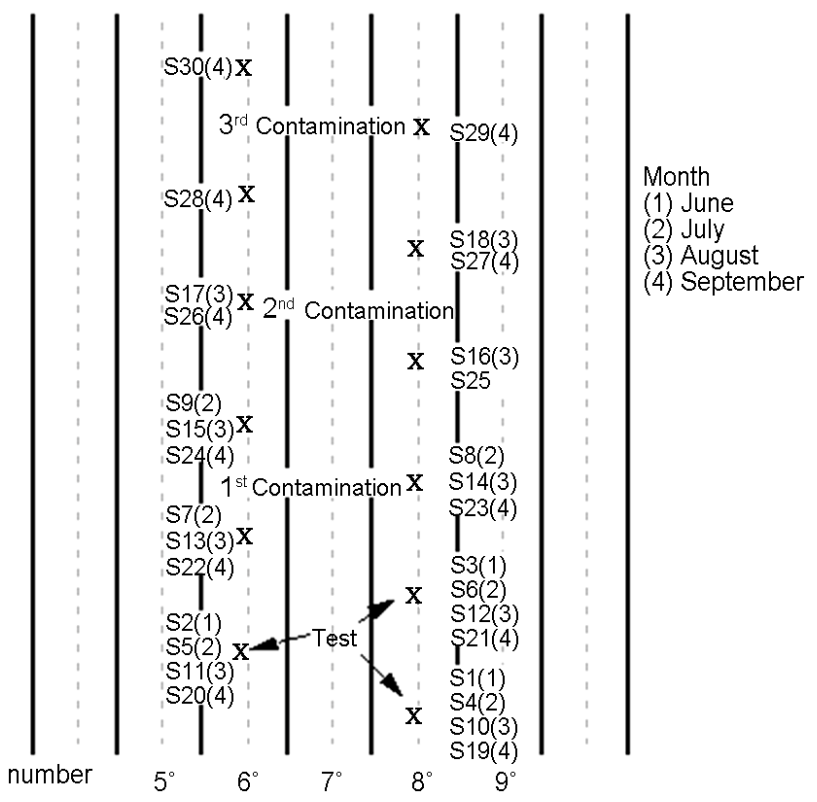

Figure 2. Samples contamination along the time. 
$25 \mathrm{~cm}$ layer (averaging the mixture within this depth). In the studies carried out by [25] to evaluate the mobility of heavy metals, their availability in plants and their immobilisation by means of chemical agents in the slimy soil of the Pas de Calais (France) area, the soils were sampled between the surface and $20 \mathrm{~cm}$.

Leaves: The $5^{\text {th }}$ leaf starting from the stem basis was collected. The preparation of the tobacco leaves was carried out in the following processes: drying in forced air stoves $\left(60^{\circ} \mathrm{C}, \mathrm{K}-\mathrm{Tarma}^{\circledR}\right)$ for 72 hours, fine grinding by hand in agate mortars and preservation in plastic containers pending analysis.

Water: Samples of the irrigation water were also taken to check its Cd contribution. Irrigation took place after the soil and tobacco leaf sampling. These water samples were taken from the water exit of the channel at the entrance of the experimental plot and on the ridges where the tobacco plants examined in this study grow. The water samples were filtered using Whatman No. 42 paper and kept in a cold store pending analysis.

\subsection{Treatments}

\subsubsection{Plants. Trace Elements: Totals}

Acid mineralisation proposed by [26]. In those samples where dilution has been necessary it has been carried out with $4 \%$ (vol.) purified water in $\mathrm{HNO}_{3}$ (placed in polyethylene tubes for storage pending analysis), the $\mathrm{Cd}$ in the resulting dissolution can be determined by GF-AAS.

\subsubsection{Soils. Trace Elements: Fractions}

The extraction of trace elements in the exchangeable fraction was carried out by shaking with extracting solution Calcic Chloride 0.001 M [27]. Extraction of trace elements joined to organic matter and oxides with EDTA $0.05 \mathrm{M}$ [28]. Extraction of trace elements joined to carbonates was carried out with Acetic Acid 0.43 M [29]. Extraction of trace elements in the soluble fraction with purified water and subsequent filtering, these were acidified with nitric acid for their preservation pending analysis [30]. Extraction of bioavailable trace elements with DTPA $0.005 \mathrm{M}, \mathrm{CaCl}_{2} \cdot 2 \mathrm{H}_{2} \mathrm{O} 0.01 \mathrm{M}$, TEA $0.1 \mathrm{M}$ extracting solution, followed by filtering with Whatman No. 42 paper [31].

In the present study cadmium has been determined with an atomic absorption Perkin-Elmer spectrophotometer AS-Analyst 300 model, provided with an HGA800 graphite oven, connected to a personal computer with AAWINLAB software with a PRINTER HPDJ-870 printer and a mass spectrophotometer with a PerkinElmer Sciex-Elan 5000 ionising fountain by a plasma torch and quadruple ion filter. Rh was used as an internal standard, with an accuracy of $\pm 2 \%$ and $\pm 5 \%$ for an analytic concentration of between 50 and 5 ppm respectively.

\section{Results and Discussion}

The contents of $\mathrm{Cd}$ in the analysed channel waters (Table 1), plot and ridges have decreasing values as we approach the tobacco growing area. The amounts of Cd fluctuate between a maximum of $0.638 \mu \mathrm{g} / \mathrm{L}$, in May, in the channel that takes the waters to the plantations, and a minimum value, in the planting ridges, with $0.277 \mu \mathrm{g} / \mathrm{L}$ of $\mathrm{Cd}$ in the same month, which coincide with the levels proposed by [32] as normal values for shallow waters.

The Cadmium concentration within the different soil fractions are shown in Table 2.

The $\mathrm{Cd}^{2+}$ ions found in the soil solution Table 2(I) are easily available for absorption by the plant [33], although the $\mathrm{pH}$ in the soil regulates its availability (Robards and Worstold, 1991), since, whilst for $\mathrm{pH}$ acids (4 - 6) Cd has a high mobility, this decreases as $\mathrm{pH}$ levels $(6-8)$ increase. The soluble fraction of cadmium presents values between $0.0005 \mathrm{mg} / \mathrm{kg}$ and $0.0191 \mathrm{mg} / \mathrm{kg}$ and, if we bear in mind that the average $\mathrm{pH}$ in water is 7.7 and its average content in $\mathrm{CaCO}_{3}$ is $25.5 \%$ [24], the cadmium content in the soluble fraction does not exceed $1.94 \%$ of the total of this metal in the soil.

In the exchangeable fraction Table 2(II) Cd contents fluctuate between 0.107 and $0.012 \mathrm{ppm}$, and represent $11.09 \%$ of the total cadmium content in the soil, which is lower than that found in the soils of Korean mining areas by [34], and reflects a Cd percentage in the exchangeable fraction with regard to the total.

When cadmium is precipitated as a carbonate or absorbed in the limestone surface, it is only soluble if there is chemical alteration, which can occur because of the "ripplesphere" effect. Due to the soil characteristics and its average content of $\mathrm{CaCO}_{3}$ (25.5\%; [24]), this fraction is the one more widely absorbed by $\mathrm{Cd}$, as has been highlighted by numerous authors $([2,35,36])$. The values determined in the carbonated fraction Table 2(III) fluctuate between 0.090 and $0.271 \mathrm{mg} / \mathrm{kg}$, with an average percentage of $34.32 \%$ of the total Cd in the soil.

The Cd fraction in the soil joined to organic matter is scarcely available and can emigrate in depth, especially when organometalic complexes are formed between $\mathrm{Cd}$ and humus substances, as well as with other high molecular weight compounds. The values of $\mathrm{Cd}$ joined with this fraction Table 2(IV) fluctuate between 0.0608 and

Table 1. Cd content in the irrigation water throughout the experiment.

\begin{tabular}{ccccc}
\hline & \multicolumn{4}{c}{ Cd in irrigation water $(\mu \mathrm{g} / \mathrm{L})$} \\
\cline { 2 - 5 } & May & June & July & August \\
\hline Conduit & 0.638 & 0.636 & 0.515 & 0.433 \\
Plot & 0.304 & 0.476 & 0.359 & 0.421 \\
Ridges & 0.277 & 0.438 & 0.346 & 0.300 \\
\hline
\end{tabular}


Table 2. Cd concentration $(\mathrm{mg} / \mathrm{kg})$ in different soil fractions.

\begin{tabular}{|c|c|c|c|c|c|c|}
\hline & Sample & $\begin{array}{c}\text { I } \\
\text { Soil Solution } \\
\text { Cd (mg/kg) }\end{array}$ & $\begin{array}{c}\text { II } \\
\text { Exchangeable } \\
\text { Cd (mg/kg) }\end{array}$ & $\begin{array}{c}\text { III } \\
\text { Carbonate Cd } \\
(\mathrm{mg} / \mathrm{kg})\end{array}$ & $\begin{array}{c}\text { IV } \\
\text { Organically } \\
\text { Bound } \\
\text { Cd (mg/kg) }\end{array}$ & $\begin{array}{c}\mathrm{V} \\
\text { Bioavailability } \\
\text { Cd (mg/kg) }\end{array}$ \\
\hline \multirow[t]{2}{*}{ Month Sample } & \multicolumn{6}{|c|}{ Test } \\
\hline & S1 & 0.0031 & 0.071 & 0.189 & 0.0911 & 0.0379 \\
\hline \multirow[t]{3}{*}{ June } & S2 & 0.0027 & 0.062 & 0.160 & 0.0804 & 0.0405 \\
\hline & S3 & 0.0029 & 0.058 & 0.156 & 0.0773 & 0.0387 \\
\hline & S4 & 0.0024 & 0.058 & 0.153 & 0.0750 & 0.0402 \\
\hline \multirow[t]{3}{*}{ July } & S5 & 0.0050 & 0.054 & 0.153 & 0.0781 & 0.0441 \\
\hline & S6 & 0.0035 & 0.057 & 0.154 & 0.0768 & 0.0417 \\
\hline & S10 & 0.0028 & 0.072 & 0.189 & 0.0914 & 0.1706 \\
\hline \multirow[t]{3}{*}{ August } & S11 & 0.0007 & 0.061 & 0.158 & 0.0746 & 0.1510 \\
\hline & S12 & 0.0015 & 0.058 & 0.151 & 0.0738 & 0.1744 \\
\hline & S19 & 0.0167 & 0.042 & 0.164 & 0.0916 & 0.0388 \\
\hline \multirow{3}{*}{ September } & S20 & 0.0191 & 0.042 & 0.172 & 0.0954 & 0.0369 \\
\hline & S21 & $0.0188 \mathrm{M}$ & 0.029 & 0.138 & 0.0810 & 0.0384 \\
\hline & S.mean average & 0.0066 & 0.055 & 0.161 & 0.0822 & 0.0711 \\
\hline & \multicolumn{6}{|c|}{$1^{\text {st }}$ Contamination } \\
\hline \multirow{4}{*}{ July } & S7 & 0.0041 & 0.058 & 0.156 & 0.1568 & 0.6251 \\
\hline & S8 & 0.0020 & 0.054 & 0.144 & 0.1474 & 0.6104 \\
\hline & S9 & 0.0015 & 0.072 & 0.185 & $0.1608 \mathrm{M}$ & $0.6876 \mathrm{M}$ \\
\hline & S13 & 0.0018 & 0.069 & 0.180 & 0.1155 & 0.0994 \\
\hline \multirow[t]{3}{*}{ August } & S14 & $0.0005 \mathrm{~m}$ & 0.099 & 0.249 & 0.1363 & 0.1425 \\
\hline & S15 & 0.0010 & $0.107 \mathrm{M}$ & $0.271 \mathrm{M}$ & 0.1475 & 0.1159 \\
\hline & S22 & 0.0181 & 0.030 & 0.140 & 0.0806 & 0.0434 \\
\hline \multirow{3}{*}{ September } & S23 & 0.0155 & 0.025 & 0.117 & 0.0705 & 0.0455 \\
\hline & S24 & 0.0169 & $0.012 \mathrm{~m}$ & $0.090 \mathrm{~m}$ & $0.0608 \mathrm{~m}$ & 0.0439 \\
\hline & S.mean average & 0.0068 & 0.058 & 0.170 & 0.1196 & 0.2682 \\
\hline & \multicolumn{6}{|c|}{$2^{\text {nd }}$ Contamination } \\
\hline \multirow{4}{*}{ August } & S16 & 0.0168 & 0.058 & 0.203 & 0.1503 & 0.3040 \\
\hline & S17 & 0.0151 & 0.038 & 0.147 & 0.1289 & 0.3243 \\
\hline & S18 & 0.0152 & 0.038 & 0.147 & 0.1277 & 0.3118 \\
\hline & S25 & 0.0181 & 0.031 & 0.142 & 0.0830 & 0.0372 \\
\hline \multirow{3}{*}{ September } & S26 & 0.0160 & 0.041 & 0.157 & 0.0862 & $0.0353 \mathrm{~m}$ \\
\hline & S27 & 0.0170 & 0.028 & 0.130 & 0.0769 & 0.0362 \\
\hline & S.mean average & 0.0164 & 0.039 & 0.154 & 0.1088 & 0.1748 \\
\hline \multicolumn{7}{|c|}{$3^{\text {rd }}$ Contamination } \\
\hline \multirow{5}{*}{ September } & S28 & 0.0124 & 0.041 & 0.147 & 0.0830 & 0.0367 \\
\hline & S29 & 0.0109 & 0.042 & 0.143 & 0.0809 & 0.0406 \\
\hline & S30 & 0.0110 & 0.041 & 0.141 & 0.0800 & 0.0375 \\
\hline & S.mean average & 0.0114 & 0.410 & 0.144 & 0.0813 & 0.0383 \\
\hline & $\begin{array}{l}\text { S.total mean } \\
\text { average }\end{array}$ & 0.0091 & 0.052 & 0.161 & 0.099 & 0.148 \\
\hline \multicolumn{2}{|c|}{ \% Cd relationship to the total } & 1.94 & 11.09 & 34.32 & 21.10 & 31.55 \\
\hline
\end{tabular}


$0.1608 \mathrm{ppm}$. The average percentage with regard to the total Cd in the soil is $21.10 \%$, which represents approximately one fourth of the total Cd. According to [37] these heavy metals are more soluble than the inorganic precipitates, which is of great relevance for the cadmium dynamics in the soil.

If we understand by bioavailability the tendency of metals, and of $\mathrm{Cd}$ to be precise, to penetrate biological systems, the concentration of this fraction is indicative of the degree of transference to plants [38]. The samples analysed within the fraction of bioavailable Cd in the soil Table 2(V) fluctuate between 0.0353 and $0.6876 \mathrm{ppm}$, with $31.55 \%$ of cadmium content with regard to the total existing in the soil.

As to dried tobacco leaves grown in a typic Xerofluvent [21] of the Granada Plain, using RJ-36 tobacco variety, the amounts of $\mathrm{Cd}$ obtained are between 0.747 and 1.673 ppm (Table 3).

Analysing the evolution of the Cd content in the different soil fractions during the experimental period (Table 2), we can indicate that in the first contamination increases in Cd percentages can be detected in the different fractions, which are specially significant in the case of the bioavailable fraction with $277.2 \%$ and of the one bound to organic compounds (45.5\%).

In the second contamination the Cd content in the soil solution and the bioavailable one is increased (148.5\%) (145.8\%), whilst the Cd in the exchangeable fraction and that bound to carbonates decreases considerably.

In the third contamination there are generalised decreases in Cd in every soil fraction, except in the soil solution, where the Cd content remains as $75.3 \%$ of the initial value, but with a decrease of $73.2 \%$ with regard to the amounts detected within the same fraction in the second contamination.

The evolution of the Cd content in the dried leaves of the tobacco plants (N Tabacum, cvs RJ-36), can be seen in Table 3, where a great increase in the accumulation of Cd can be observed in the first and second contaminations, whilst in the third there is a significant decrease (18.7\%) of the Cd content in the dried leaves after the

Table 3. Cd content $(\mathrm{mg} / \mathrm{kg})$ of dried tobacco leaves in the different treatments.

\begin{tabular}{cccccccc}
\hline \multicolumn{7}{c}{ Dry Leaf } \\
\hline Sample & $\begin{array}{c}\text { Cd } \\
(\mathbf{m g} / \mathbf{k g})\end{array}$ & Sample & $\begin{array}{c}\text { Cd } \\
(\mathbf{m g} / \mathbf{k g})\end{array}$ & Sample & $\begin{array}{c}\text { Cd } \\
(\mathbf{m g} / \mathbf{k g})\end{array}$ & Sample & $\begin{array}{c}\text { Cd } \\
(\mathbf{m g} / \mathbf{k g})\end{array}$ \\
\hline H1 & 0.771 & H4 & 0.881 & H7 & $1.673 \mathrm{M}$ & H10 & 1.160 \\
H2 & 0.747 m & H5 & 1.050 & H8 & 1.361 & H11 & 1.089 \\
H3 & 0.763 & H6 & 1.391 & H9 & 1.309 & H12 & 1.283 \\
\hline
\end{tabular}

$\mathrm{M}=$ Maximun value; $\mathrm{m}=$ Minimum value; H1-2-3 = Test; H4-5-6 = $1^{\text {st }}$ Contamination; H7-8-9 $=2^{\text {nd }}$ Contamination; H10-11-12 $=3^{\text {rd }}$ Contamination. third contamination. This evolution has a parallelism with the one detected for the Cd content in the different soil fractions.

\section{Conclusions}

As conclusions we can state that the average content of $\mathrm{Cd}(\mu \mathrm{g} / \mathrm{L})$ in the irrigation waters reaching the tobacco crops (ridges) is of $0.340(\mu \mathrm{g} / \mathrm{L}$, and the recommended concentrations are of $0.01 \mathrm{mg} / \mathrm{L}$, for frequent irrigation waters in this type of crops [39], and in soil with $\mathrm{pH}$ between 6.0 and 8.5. When they are used for extended periods of time, it is advisable that the Cd concentration in that water should not exceed $0.05 \mathrm{mg} / \mathrm{L}$. Therefore, the water used for irrigation is not a contamination risk for the soil even when used over lengthy periods of time.

When cadmium bound to exchangeable soluble fractions is extracted, carbonates, organic matter and oxides, as well as bioavailable fraction we can observe that:

The fraction presenting higher average values is the one of cadmium bound to $\mathrm{CaCO}_{3}$ with $0.161 \mathrm{ppm}$, and we shall show that cadmium tends to be fixed to this fraction.

The Cd-bioavailable fraction is second in importance after the carbonated one and we propose a Cd content sequence in fractions from higher to lower, which is as follows:

Cd-Carbonates > Cd-Bioavailable > Cd-M.O. $>$ CdExchangeable $>$ Cd-Soluble.

The novelty of this work is due to the prediction of cadmium content in different soil fractions after a standar contmination and the consequence in tobacco leaves after being dried and ready for processing.

\section{REFERENCES}

[1] C. Cabrera, E. Ortega, M. L. Lorenzo and M. C. López, "Cadmium Contamination of Vegetable Crops, Farmlands, and Irrigation Waters," Reviews of Environmental Contamination and Toxicology, Vol. 154, 1998, pp. 55-81.

[2] B. J. Alloway, "Cadmium. En: Heavy metals in Soils,” In: B. J. Alloway, Ed., 2nd Edition, Blackie Academic Professional, London, 1995, pp. 122-151.

[3] M. Hutton and C. Symon, “The Quantities of Cadmium, Lead, Mercury and Arsenic Entering the U.K. Environment from Human Activities," Science of the Total Environment, Vol. 57, 1986, pp. 129-150. http://dx.doi.org/10.1016/0048-9697(86)90018-5

[4] C. Cabrera, M. L. Lorenzo, C. Gallego, M. C. Lopez and E. Lillo, "Niveles de Cadmio en Aguas de la Costa de Granada,” Ars Pharmaceutica, Vol. 19, Tomo II, 1992, pp. 945-950.

[5] B. Sangster, G. De Groot, J. G. Loeber, H. J. G. M. Derks, E. I. Krajnc and T. J. F. Savelkoul, "Urinary Excretion of Cadmium, Protein, Beta-2-Microglobulin and Glucose in Individuals Living in a Cadmium-Polluted Area,” Human 
\& Experimental Toxicology, Vol. 3, No. 1, 1984, pp. 7-21. http://dx.doi.org/10.1177/0960327184003001021

[6] J. M. Azcue, "Metales en el Medio Ambiente. En: Metales en Sistemas Biológicos,” In: A. Mas and J. M. Azcue, Eds., Ediciones PPV, S.A. Barcelona, 1993, pp. 163-186.

[7] A. Kabata-Pendias and H. Pendias, "Trace Elements in Soil and Plants," 3rd Edition, CRC Press, Boca Raton, 2001.

[8] C. Cabrera, E. Ortega, C. Gallego, M. C. López, M. L. Lorenzo and C. Asensio, "Cadmium Concentration in Farmlands in Southern Spain: Possible Sources of Contamination," Science of the Total Environment, Vol. 153, No. 3, 1994, pp. 261-265. http://dx.doi.org/10.1016/0048-9697(94)90206-2

[9] G. S. Bañuelos and H. A. Ajwa, "Trace Elements in Soils and Plants: And Overview," Journal of Environmental Science and Health, Vol. 34, No. 4, 1999, pp. 951-974. http://dx.doi.org/10.1080/10934529909376875

[10] U. Förstner, "Metal Speciation and Contamination of Soil,” CRC Press, Boca Raton, 1995, pp. 1-33.

[11] L. Ramos, L. M. Hernández and M. J. González, "Sequential Fractionation of Copper, Lead, Cadmium and Zinc in Soil from or Near Doñana National Park,” Journal of Environmental Quality, Vol. 23, No. 1, 1994, pp. 50-57.

http://dx.doi.org/10.2134/jeq1994.00472425002300010009x

[12] CMA, “Los Criterios y Estándares para Declarar un Suelo Contaminado en Andalucía y la Metodología y Técnicas de Toma de Muestras y Análisis para su Investigación,” Informe de las Universidades de Granada, Huelva y Sevilla, Consejería de Medioambiente, Junta de Andalucía, 1999.

[13] A. Tessier, P. G. C. Campbell and M. Bisson, "Sequential Extraction Procedure for the Speciation of Particulate Trace Metals,” Analytical Chemistry, Vol. 51, No. 7, 1979, pp. 844-851. http://dx.doi.org/10.1021/ac50043a017

[14] WHO, "Environmental Health Criteria 134: Cadmium," World Health Organization, Geneva, 1992, 280 p.

[15] WHO, "Cadmiun: Environmental Aspects. Environmental Health Criteria, 135,” World Organization, Geneva, 1992, p. 156.

[16] R. Eisler, "Cadmium Hazards to Fish, Wildlife and Invertebrates: A Synoptic Review," US Department of the Interior, Fish and Wildlife Service, Washington DC, 1985.

[17] B. E. Davies, "Cadmium in Sludge Used as Fertilizer," Experientia, Vol. 40, 1984, pp. 117-126.

[18] B. B. Clarke and E. Brennan, "Tobacco Leaves Accumulate Cadmium from Root Aplications of the Heavy Metal,” Tobacco Science, Vol. 27, 1983, pp. 28-29.

[19] A. J. Mac Lean, "Cd in Different Plant Species and Its Availability in Soils as Influenced by Organic Matter and Additions of Lime, P, Cd and Zn," Canadian Journal of Soil Science, Vol. 56, 1976, pp. 129-138. http://dx.doi.org/10.4141/cjss76-021

[20] Servicio Geográfico del Ejercito, "Hoja Topográfica de Granada-1009,” Darío Gazapo, No. 8, 1989, Granada.

[21] NRCS-USDA, “Keys to Soil Taxonomy,” 11th Edition,
NRCS, Lincoln, 338 p.

[22] WRB-FAO, "World Reference Base for Soil Resources," World Soil Resources Report, No. 103, FAO, Roma, 2006, $145 \mathrm{p}$.

[23] W. E. Sabbe and D. B. Marx, "Soil Sampling: Spatial and Temporal Variability. En Soil Testing: Sampling, Correlation, Calibration, and Interpretation,” SSSA Special Publication, Madison, 1987, p. 8.

[24] E. Pérez, "Estudio de Contaminación por Cadmio en Suelos y Plantas de Tabaco,” Tesis Doctoral, Universidad de Granada, Granada, 2001.

[25] M. Mench, J. Vanggronsveld, V. Didier and H. Clijster, "Evaluation of Metal Mobility, Plant Avaibility and Inmobilization by Chemical Agents in a Limed-Silty Soil," Environmental Pollution, Vol. 86, 1994, pp. 279-286. http://dx.doi.org/10.1016/0269-7491(94)90168-6

[26] G. J. Wagner and M. M. Trotter, "Inducible Cadmium Binding Complexes of Cabbage and Tobacco,” Plant Physiology, Vol. 69, 1982, pp. 804-809. http://dx.doi.org/10.1104/pp.69.4.804

[27] I. Novozamsky, T. H. Lexmond and V. J. Houba, “A Single Extration Procedure of Soil for Evaluation of Uptake of Some Heavy Metals by Plants," International Journal of Environmental Analytical Chemistry, Vol. 51, 1993, pp. 47-58. http://dx.doi.org/10.1080/03067319308027610

[28] Ph. Quevauviller, M. Lachica, E. Barahona, A. Gómez, G. Rauret, A. Ure and H. Muntan, "Certified Reference Material for the Quality Control of EDTA and DTPA Extractable Trace Metal Contens in Calcareous Soils (CRM 6000)," Fresenius Journal of Analytical Chemistry, Vol. 360, 1998, pp. 505-511. http://dx.doi.org/10.1007/s002160050750

[29] A. M. Ure, Ph. Quevauviller, H. Muntau and B. Griepink, "Especiation of Heavy Metal in Soils and Sediments. An Account of the Improvement and Harmonisation of Extration Techniques Undertaken under the Auspices of the BCR of the Commision of the European Communities," International Journal of Environmental Analytical Chemistry, Vol. 51, 1993, pp. 135-151. http://dx.doi.org/10.1080/03067319308027619

[30] L. Allison, "Oversaturation. Method for Preparing Saturation Extract for Salinity Appraisal,” Soil Science, Vol. 116, 1973, pp. 65-69. http://dx.doi.org/10.1097/00010694-197308000-00001

[31] D. E. Baker and M. C. Amacher, "Nickel, Copper, Zinc and Cadmium,” Methods of Soil Analysis, No. 9, Part II, 1982, Madison, pp. 331-333.

[32] J. M. Concon, "Food Toxicology: Contaminants and Additives,” Dekker, New York, 1988.

[33] J. Jing and T. Logan, "Effects of Sewage Sludge Cadmium Concentration on Chemical Extractability and Plant Uptake,” Journal of Environmental Quality, Vol. 21, 1992, pp. 1-8. http://dx.doi.org/10.2134/jeq1992.00472425002100010011x

[34] I. C. Kong and G. Bitton, "Correlation between Heavy Metals Toxicity and Metal Fractions of Contaminated Soils in Korea,” Bulletin of Environmental Contamination and Toxicology, Vol. 70, 2003, pp. 557-565. 
http://dx.doi.org/10.1007/s00128-003-0022-4

[35] M. B. Mc Bride, "Chemisorption of $\mathrm{Cd}^{2+}$ on Calcite Surfaces,” Soil Science Society of America Journal, Vol. 44, 1980, pp. 26-28.

http://dx.doi.org/10.2136/sssaj1980.03615995004400010 006x

[36] M. Simón, I. Ortiz, I. García, E. Fernández, J. Fernández, C. Dorronsoro and J. Aguilar, "Pollution of Soils by the Toxic Spill of a Pyrite Mine (Aznalcollar, Spain)," The Science of the Total Environment, Vol. 242, No. 1-3, 1999, pp. 105-115.

http://dx.doi.org/10.1016/S0048-9697(99)00378-2
[37] G. K. Sposito, "The Chemistry of Soils,” Oxford University Press, New York, 1989.

[38] W. A. Glooschenko and J. M. Azcue, "Metales en los Suelos," In: A. Mas and J. M. Azcue, Eds., Metales en Sistemas Biológicos, Ediciones PPV, S.A. Barcelona, 1993, p. 219.

[39] Junta de Extremadura, "Interpretación se Análisis de Suelo, Foliar y Agua de Riego. Consejo de Abonado (Normas Basicas)," Consejeria de Agricultura y Comercio, Ed. Mundi Prensa, Madrid, 1992, p. 280. 